\title{
Exchange Materials Used in College and University Libraries
}

$\mathrm{P}_{\text {Rofessional literature has devoted }}$ little attention to the important problem of interlibrary exchange. With librarians seeking adjustment to plans of service based on standards far above those of prewar days, it is worth while considering all resources and facilities which might support effective programs. This is especially true now, since so many foreign libraries are seeking exchange relationships.

There are indications that exchange relations between libraries will expand. While paper shortages still exist, they should not continue. As far back as 1930 the University of Illinois sent out in one year on exchange 10,970 copies of 92 different University of Illinois publications. Illinois, of course, had approximately 85 copies of each printed dissertation and from 10 to 25 copies of each university publication. The success of Illinois and other libraries suggests possibilities for other institutions.

This paper is therefore offered as a preliminary analysis of the problems involved in setting up a suitable and efficient exchange program. The present purposes are threefold: (I) to indicate the scope of available exchange material; (2) to determine the extent to which such material is being fully exploited; and ( 3 ) to bring together the salient points made in published material on the subject. In discussing these purposes it is assumed that full use is not being made of available exchange material and that where such materials are being used they are not being used to the best advantage.

Three limitations are present in this study. In the first place, only colleges and universities in the United States have been considered. This narrows the exchange field considerably. The division of exchanges into national and international groups, however, seems logical. Secondly, the actual dispersal of the materials is not considered, unless it has a definite bearing on the materials used. The third limitation is that what follows is concerned only with interlibrary exchange and not exchange between libraries and dealers.

Broadly speaking, exchange materials may be broken down into five categories: dissertations, university publications, duplicate books, duplicate serials, and nonduplicate materials. The tabulated results of a questionnaire (see Table) recently sent out by the Columbia University Libraries for the purpose of organizing and fostering this exchange program indicates that the three major forms of exchange material used by college and university libraries are journals, university published serials (monographic), and dissertations (whole or in abstract).

Kellar, in his "Memoranda on Library Cooperation," points out that "all libraries have some books which, to them, are a complete liability. They require housing, cataloging, and administration, and never pay dividends in terms of usage. These same books, if placed in other libraries, may 
TABLE

Exchange Materials Distributed by College and University Libraries

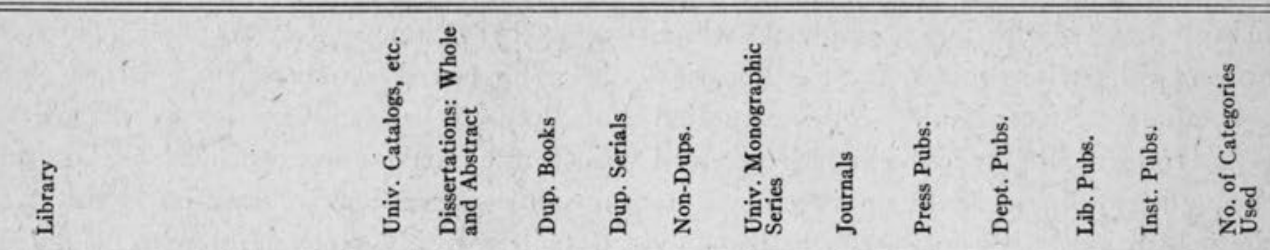

Arizona

Arkansas

Bowdoin

Brown

California

Clark

Colorado

Cornell

Delaware

Denver

Florida

Harvard-Littauer

Peabody

Iowa

Johns Hopkins $\quad x \quad x$

Joint University Libraries $\mathrm{x} \quad \mathrm{x}$

Kansas

Louisiana State

Maine

Minnesota

Missouri

Montana

Nebraska

New Mexico

Oklahoma

Oregon

Princeton

Southern California

Stanford

Temple

Tulane

Virginia

Washington (St. Louis)

Washington (Seattle)

West Virginia

Western Reserve

Wisconsin

Yale

$x \quad x$

$\mathrm{X} \quad \mathrm{X}$

$\mathbf{X}$

$\mathrm{x}$

$\mathbf{x}$

$x \quad x$

$\mathrm{x}$

$\mathrm{x}$

$\mathrm{x}$

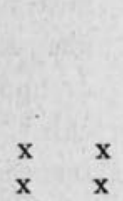

$\mathrm{x}$

$\mathbf{x}$

$\mathbf{x}$

$\mathrm{x}$

$\mathrm{x}$

$x$

$x$

$\mathrm{x}$

x $\quad x$

$\mathrm{x}$

$\mathrm{x} \quad \mathrm{x}$

$\mathrm{x}$

$\mathbf{x}$

$\mathrm{x}$
$\mathrm{x}$

$\begin{array}{ll}\mathrm{x} & \mathrm{x} \\ \mathrm{x}\end{array}$

$\mathrm{x}$

$\mathrm{x}$

x $\quad x$

$\mathrm{x}$

$\mathrm{x}$

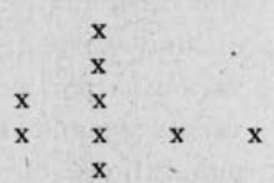

x $\quad x$

$\mathrm{x}$

$\mathrm{x}$

$\mathrm{x} \quad \mathrm{x}$

$x \quad x$

$\mathrm{x}$.

$\mathrm{x}$

\begin{tabular}{llllllllllll}
38 & Totals & 13 & 18 & 3 & 3 & 18 & 19 & 3 & 4 & 12 & 12 \\
\hline
\end{tabular}

\begin{tabular}{llllllllllll}
\hline 38 & Totals & 13 & 18 & 3 & 3 & 18 & 19 & 3 & 4 & 12 & 12 \\
\hline
\end{tabular}

$13 \quad 18$

\begin{tabular}{llllllllllll}
38 & Totals & 13 & 18 & 3 & 3 & 18 & 19 & 3 & 4 & 12 & 12 \\
\hline
\end{tabular}

$\mathrm{x} \quad \mathrm{x}$

$\begin{array}{lll}x & 5 \\ x & 4\end{array}$

$\mathrm{x}$

$\mathrm{x}$

$\mathrm{x}$

6
6

3

I 
be in active circulation, even filling in gaps difficult to bridge otherwise." ${ }^{\prime 1}$ These materials include books which are not in fields stressed by the library and books which are not otherwise suitable for the libraries' collections. An example of this situation is a college library which has received through gift many books on theology. If the institution offers no courses in theology these books may be either a waste from the point of view of handling and storage or they may be a potential asset from the point of view of exchange. Similarly, the clientele of a large research university may find of little use books on the secondary school level but they may be of definite value to users of the small college library. These types of material apparently have been generally overlooked in the exchange field. Of a total of thirty-eight libraries replying to the Columbia questionnaire, not one indicated using nonduplicate material for exchange.

Kellar definitely favors a widespread, liberal exchange policy. He points out that there are now three types of books resting on many library shelves which could be put to active use through exchange. These are duplicate copies not in use, books of general character not in use because of lack of interest, and books of a highly specialized nature outside the field of concentration of the holding institution.

On the matter of using an institution's own publications for exchange, as early as 1913 Guy Stanton Ford ${ }^{2}$ noted that any library with a well-developed and efficient exchange department can do much to accumulate valuable materials by distributing the university's own publications. Often whole literatures can be enriched with ma-

\footnotetext{
1. Kellar, Herbert A. "Memoranda on Library Cooperation." No. r. Washington, r941, p. 10.

2 Ford, Guy Stanton. "The Library and the Graduate School." Stanton. "The Library and the GraduJournal of Proceedings 15:43, 1913.
}

terials of value greater than the salary of an active exchange librarian.

The question of the use of dissertations as exchange material is one which has not been answered satisfactorily. More than one-half of all universities granting the doctorate make some provision for immediate or eventual publication of dissertations, either in whole or in part. Figures in American Universities and Colleges show that forty-two universities require publication of the dissertation, twenty-one others require abstracts only, and four additional institutions allow a choice or require only abstracts in certain fields. Sometimes these abstracts are issued as separate publications or appear in scientific or technical periodicals. $^{3}$ In any case, the exchange of dissertations is generally an effective means of disseminating the results of research and investigation. Where one of the requirements for obtaining a Ph.D. degree is the depositing of a certain number of copies of the dissertation, the basis for an important exchange relationship is provided.

University publications as a major group of exchange materials were mentioned briefly above. These publications may be broken down conveniently into the following categories: university catalogs, bulletins, and other official publications; publications of university presses; publications of the various departments of the college or university; publications of the library; and publications of societies and institutions located within the precincts of the university which are either affiliated with or are not definitely a part of the corporate body. In some cases the publications of the college or university press are available in limited quantities for exchange without cost to the library. Other institutions have an ar-

3 Marsh, Clarence Stephen, ed. American Univer. sities and Colleges, 4th ed. Washington, American Council on Education, 1940, p. 66. 
rangement whereby the library may purchase these publications at a substantial discount. On the other hand, in all too many cases, no arrangement exists for obtaining such materials for exchange.

As Fleming, Raney, and Downs point out, many librarians do not realize the quantity or scope of the potential exchange material which they have at hand. Fleming calls attention to the fact that a librarian frequently is neither aware of what the college or university press, publishes, nor does he receive stock of the publications. According to him:

The librarian should employ every available method possible to persuade the college authorities of the necessity and desirability of receiving exchange stock. The establishment of commercial college and university presses by many institutions has resulted in libraries' failing to secure any exchange stock. ${ }^{4}$

\section{University Press Publications}

In connection with the use of university press publications as exchange material, Raney suggested that a part of every issue of the press should be deposited with the library for exchange purposes without deduction from the library's budget. These issues could be used to obtain periodicals and the publications of learned societies and academies, educational institutions, and research agencies. ${ }^{5}$

Downs also emphasized the value of exchange in this way:

One of the most used materials for developing state document collections is through exchange with other institutions. A problem is how to get material which can be offered on exchange basiș. The state library and perhaps the state supreme court library, under the laws of some states, are furnished with a specific number of copies of official publications for exchange purposes. The use

4 Fleming, Thomas P. "Developing Library Resources with Limited Funds." Library Journal $63: 138$

Feb. 15, 1938. Llewellyn. The University Libraries. Chicago, University of Chicago Press, 1933, p. 17. made of this privilege has varied considerably in effectiveness. . . The problem of exchanges is one which merits more attention from research libraries. Those libraries associated with active university presses are in a particularly fortunate situation. With time and patience, extremely valuable exchange relations can be developed with learned institutions and organizations throughout the world. ... In some institutions the press is not inclined to be generous with free copies to the library, but there are probably few presses who would not sell their publications at cost to the libraries for exchange purposes. ${ }^{6}$

In large universities certain departments often issue publications under their own imprint. Whether or not these publications are sent on exchange through the library is outside the scope of this paper. The fact to be noted is that such publications do exist and that they are fit material for advantageous exchange relationships. Although the library of an institution may publish only material which is of interest or value to the profession, it is still true that a large exchange market exists where these publications are very valuable. The output of the library may consist only of a mimeographed newssheet or it may be a monographic series of bibliographical importance. A certain proportion of this material may be used for exchange purposes.

\section{Learned Societies}

Many learned societies and institutions work closely with colleges and universities in the furtherance of their aims as scholarly groups, and their journals are edited and often published under university or college sponsorship. Often arrangements can be made with these groups to set up exchange relations. Certainly the publications which are issued by these groups receive many allied journals and monographs which seek to be recognized or mentioned in these

- Downs, Robert B. "Problems in the Acquisition of Research Materials." Randall, William M., ed. The Acquisition and Cataloging of Books. Chicago, University of Chicago Press, 1940, p. 72. 
scholarly publications. It is quite easy to understand that the materials received by these societies are not going to be kept for a long period of time when facilities for handling and storage are not readily available. This is where the library might come in. It may be that the society or institution will agree to turn over to the library the publications which it receives in this manner and will allow the library to purchase subscriptions to its publications at a greatly reduced rate or even at cost. This is an indirect exchange procedure, but the ultimate effect is similar to that resulting from a more direct method.

Although lists of duplicate books for exchange are common in most college and university libraries, the answers to the questionnaire issued by the Columbia University Libraries indicate that three of the thirty-seven libraries supplying data use duplicate books as exchange material ( $\mathrm{Ta}$ ble.) Most libraries probably avoid using duplicate books as exchange material because so much time and money are involved in the preparation of lists. It may be that the answer to this objection is the formation of more and better exchange unions. Perhaps a re-examination of the question of duplicate books would awake in the minds of librarians a fuller realization of the value of this material when used for exchanges.

In a similar vein, duplicate serials are often an excellent source for exchange materials. But here, too, only three libraries make use of serials in this way. The problem again is one of cost in listing the serials available. At present a great many libraries are probably concentrating on saving their duplicate serials for the devastated libraries of Europe. This commendable practice has a further advantage of requiring less listing (or perhaps none). However, should there not be a plan for the use of these materials after the present crisis in European libraries is over?

At any rate, it is advisable to remember that serial duplicates have value above and beyond their use as replacements within a single institution. Downs points out:

The question of duplicate exchanges has never been put on a systematic basis except perhaps by the medical librarians. There is no doubt that quantities of duplicate material in all fields exist, taking up needed space in libraries and of no use to the possessors. The labor and expense of detailed listings and record-keeping have discouraged librarians from disposing of these accumulations. ${ }^{\text {? }}$

Fleming suggests that, in gathering a stock of materials to use for exchange, an effort be made to acquire a quantity of back issues of publications of a college. Every library has a long list of desiderata "either literally or figuratively. Now, if a library were to actually purchase all the desirable items which cross its path, there would be little money left for any purposes, including salaries. It is possible, however, to acquire a great many desirable items from the duplicates of other libraries merely for the cost of transportation." this a supply of materials must be kept on hand to be offered in exchange for materials obtained.

In comparison with the figures from the Columbia libraries' questionnaire, Terry's findings may be noted. ${ }^{9}$ Of 225 libraries reporting, 5 did not check the kind of materials used for exchange; 123 checked college or university publications; 34 , dissertations; 95, duplicate books; 12 I, duplicate serials; and 107, duplicate serials and continuations. In other words, 20 of the libraries reporting used all five of these types of exchange materials; 45 used all but dis-

\footnotetext{
'Op. cit., p. 73.

Op. cit. p. 139. "A List of College and University Publications Available as Exchanges." (Unpublished master's essay.) Columbia University, 1939.
} 
sertations; 14 used duplicate serials and continuations. Of all libraries reporting in 1939, the most-used type of exchange material was college and university publications. Today college and university publications again rank first as exchange material, with dissertations next. In regard to the number of types of materials used by individual colleges, I uses seven, 2 use six, and 3 use five. These figures represent replies from 38 institutions regarding eleven different categories of materials. It should be pointed out, however, that the questionnaire sent out by Columbia does not represent a full and complete report from those libraries which answered the questionnaire; in other words, these answers reflect only the situation between the libraries reporting and Columbia. It may be that the reporting libraries use other materials for exchange than those which they send to Columbia.

\section{Other Materials}

Two other forms of exchange material should be mentioned: microfilm and documents issued by state, city, or other government agencies. Microfilm has not been specifically included in the foregoing statements since it represents, first of all, a class in itself; and, secondly, it is not yet significant as an exchange item. However, it is probablê that microfilm can and will play an important part in exchange relationships in the near future. Official documents have not been separately classed in this discussion because these are considered, not so much as documents, but rather as books or serials. Therefore, they fit into the classifications already mentioned.

Miscellaneous materials used for exchange purposes may include newspapers; trade catalogs; annual reports of companies and societies; and financial reports, histories, directories, and similar publications of col- leges and universities.

Ivander MacIver's articles on exchange have been mainly concerned with serial publications, but her observations may be applied to all groups of exchange materials. She contends that the library should not have to pay from the book fund for materials used for exchange. Another point which MacIver makes is that there is a definite tendency to get materials in the same fields as those in which libraries offer materials on exchange. Thus, there is a tendency to offer a series in return for a series.

\section{Summary}

In summary, it may be stated that many librarians in colleges and universities do not realize the potentialities for exchange purposes of their available materials, which may consist of at least twelve categories. Briefly, these categories may be listed as follows: (I) university catalogs, bulletins, and other official publications; (2) dissertations-whole or in abstract; (3) duplicate books; (4) duplicate serials; (5) nonduplicate materials; (6) university published serials-monographic; (7) university published journals; $(8)$ university press publications; (9) department publications; (Io) library publications; ( II) society and institute publications; (12) miscellaneous materials including such items as microfilm, catalogs, newspapers, and pamphlets. Generally speaking, the sources of material to be used for exchange can be divided into five groups: by deposit (as with government publications), by gift, by purchase, by arrangement with the publisher (university press publications), and by discarding from the libraries' collections. There is much that can be done to bring increased benefits from exchanges, and now is the time to start doing it. 